$$
\begin{array}{r}
\text { AS EXPERIÊNCIA } \\
\text { DIVERSIDADE SEXUAL } \\
\text { GÊERO EM QUILOMBOS } \\
\text { NORDESTE E DO NORTE } \\
\text { BRASIL: PARA INÍCIC } \\
\text { CONVE }
\end{array}
$$




\section{AS EXPERIÊNCIAS DA DIVERSIDADE SEXUAL E DE GÊNERO EM QUILOMBOS DO NORDESTE E DO NORTE DO BRASIL: PARA INÍCIO DE CONVERSA.}

\section{F A B I A N O G O N T I J O}

PROFESSOR ASSOCIADO, PPGA/UFPA.

B RUNO RODRIGO CARVALHO DOMINGUES

BACHARELANDO EM CIÊNCIAS SOCIAIS, UFPA.

I G O R E R I C K

BACHARELANDO EM ANTROPOLOGIA, UFOPA 


\section{AS EXPERIÊNCIAS DA DIVERSIDADE SEXUAL E DE GÊNERO EM QUILOMBOS DO NORDESTE E DO NORTE DO BRASIL: PARA INÍCIO DE CONVERSA.}

\section{Resumo \\ Trata-se aqui de iniciar uma reflexão sobre as experiências da diversidade sexual e de gênero em contextos quilombolas brasileiros - a partir de um quilombo situado na região Nordeste e um outro, na região Norte -, com base na crítica às lacunas apresentadas tanto nos estudos sobre etnicidade e/ou sobre quilombos quanto nos estudos de gênero e sexu- alidade no que diz respeito a essa experiência. \\ Palavras-chave: quilombos, diversidade sexual e de gênero, marcadores sociais da diferença.}

\section{THE EXPERIENCES OF SEXUAL AND GENDER DIVERSITY IN QUILOMBOS OF THE NORTHEASTERN AND NORTHERN RE- GIONS OF BRAZIL: TO BEGIN WITH}

\footnotetext{
Abstract

This paper presents a preliminary discussion on the experiences of sexual and gender diversity in the context of Brazilian quilombos - from a quilombo situated in the Northeastern and another in the Northern region of the country - based on the criticism on the presented gaps both in the studies about ethnicity and/or quilombos and in the studies of gender and sexuality with regard to this experience.

Keywords: Quilombos, sexual and gender diversity, markers of social difference.
} 


\section{LAS EXPERIENCIAS DE LA DIVERSIDAD SEXUAL Y DE GÉNE- RO EN COMUNIDADES DE CIMARRONES EN EL NORDESTE $Y$ EN EL NORTE DE BRASIL: PARA DAR INICIO A LA CONVER- SACIÓN}

\section{Resumen}

El texto intenta dar inicio a una reflexión sobre las experiencias de diversidad sexual y de género en contextos de quilombos brasileros - a partir de una comunidad de cimarrones ubicada en la región Nordeste y otra en la región Norte- basada en una crítica tanto a los vacíos presentes en los estudios de etnicidad y/o sobre quilombos, como en los estudios de género y de sexualidad en lo que concierne a esta experiencia.

Palabras clave: comunidades de cimarrones, diversidad sexual y de género, marcadores sociales de diferencia.

Endereço do autor para correspondência: Avenida Presidente Vargas, 499/402. Bairro Campina. CEP: 66017-000. Belém - PA. 


\section{APRESENTAÇÃO}

Quando se pensa em quilombos no Brasil, as imagens que vêm à mente talvez sejam, num primeiro momento, aquelas dos dolorosos movimentos históricos de resistência, acrescidas daquelas, não menos dolorosas, dos processos étnicos e políticos de reivindicação territorial atuais de descendentes de africanos escravizados no passado colonial. Falar de quilombo é, pois, tratar de origens e raízes, reminiscências e tradições, ancestralidade, heranças e diferenças culturais, adaptação e resistência, territórios e conflitos, etc. Há uma vasta literatura brasileira sobre quilombos e quilombolas, englobando as mais diversas áreas do conhecimento, sobretudo as Ciências Humanas devido às especificidades identitárias e às reivindicações territoriais, que levam a um interesse maior por parte de historiadores, antropólogos, sociólogos e juristas pela "questão quilombola". ${ }^{1}$ Essa literatura aborda basicamente as temáticas relativas a essas duas imagens, dentre outras mais. Nela, não conseguimos achar estudos específicos sobre as experiências da diversidade sexual e de gênero em contextos quilombolas ${ }^{2}$.

Diante de tal constatação, resolvemos iniciar uma reflexão sobre essas experiências a partir dos resultados preliminares das análises de algumas narrativas biográficas ou relatos de vida de quatro rapazes de dois quilombos - um situado na Mata dos Cocais, no norte do estado do Piauí; o outro, na Amazônia paraense. Sendo assim, o/a leitor/a não encontrará nesse artigo qualquer tentativa de produção de um "estado da arte" dos estudos sobre quilombos e quilombolas no Brasil, nem fronteiras étnicas e etnicidade, territorialidades específicas, conflitos de base étnica, etc. Não era esse o nosso objetivo. A nossa intenção é a de apresentar um esboço de interpretação sobre a maneira como alguns homens quilombolas falam de suas vidas e, assim, constroem socialmente e formulam culturalmente suas experiências, quando são considerados pelos seus pares como homens que se relacionam afetiva e sexualmente com outros homens. Essas vidas afetivas se desenrolam obviamente em meio a definições de fronteiras étnicas, territorialidades específicas, conflitos de base étnica, etc.

\section{DOS QUILOMBOS AOS QUILOMBO- LAS}

Segundo Marques e Gomes (2013: 137), “[o] reconhecimento do direito ao território no qual as comunidades negras desenvolvem seus modos de fazer e viver tem sido garantido em diversas Constituições na América Latina." As lutas e reinvindicações dos movimentos sociais e das comunidades rurais negras na década de 1970 e as mudanças políticas ocorridas na década de 1980 desembocaram na Constituição de 1988 e a garantia do reconhecimento da propriedade definitiva das terras ocupadas por "remanescentes das comunidades de quilombos", conforme estipulado pelo Artigo 68 do Ato das Disposições Constitucionais Transitórias (ADCT). Em 2003, o Decreto Presidencial 4.887 de 20 de novembro regulamentaria o Artigo 68 
do ADCT. O Artigo $2^{\circ}$ desse Decreto define os sujeitos quilombolas da seguinte maneira:

"Consideram-se remanescentes das comunidades dos quilombos, para os fins deste Decreto, os grupos étnico-raciais, segundo critérios de auto atribuição, com trajetória histórica própria, dotados de relações territoriais específicas, com presunção de ancestralidade negra relacionada com a resistência à opressão histórica sofrida."

Uma ampla discussão crítica se desencadeou a partir desse marco jurídico para deliberar sobre a validade de categorias como "remanescentes" (pensada como algo que estaria em vias de extinção) e "quilombos" (pensada como uma unidade fechada e coesa), como bem observou Leite (2000). A expressão "remanescentes das comunidades de quilombos" suscitou muitos questionamentos sobretudo por "não corresponder à autodenominação destes mesmos grupos, e por tratar-se de uma identidade ainda a ser politicamente construída" àquela altura (Leite 2000: 341). Destacou ainda que "a vastidão de significados, como concluem vários estudiosos da questão, favorece o seu uso para expressar uma grande quantidade de experiências, um verdadeiro aparato simbólico a representar tudo o que diz respeito à história das Américas" (Leite 2000: 341). A partir daí, desenvolveu-se uma série de estudos para problematizar a categoria "quilombo" e tornar mais visível o protagonismo político dos sujeitos quilombolas, suas múltiplas formas organizativas e seus diversos processos de produção de pertencimento étnico. Esses estudos geralmente se baseavam na percepção de que as construções identitárias são flexíveis, os pertencimentos, porosos, e os fluxos culturais, dinâmicos.

A pluralidade de significados acerca do sujeito quilombola, aliado ao "racismo à brasileira” (DaMatta 1987; Guimarães 2004; Munanga 2007; Nogueira 2007), pode ter acarretado uma espécie de folclorização (por que não dizer fetichização") das questões relativas às realidades identitárias quilombolas. Para demonstrar essa folclorização, Leite (1999: 125) citou seu incômodo diante de perguntas que lhe foram feitas em duas ocasiões: na primeira, a autora é perguntada sobre o que é um remanescente de quilombo? e se seria possível, durante um voo, reconhecer, entre os passageiros da aeronave, um remanescente; na segunda, a autora é indagada por um professor do ensino básico sobre onde ele poderia encontrar um quilombo verdadeiro para levar seus alunos em uma excursão.

Durante os preparativos de nossa pesquisa, essa "folclorização" tomou a forma de perguntas, por parte de alguns colegas acadêmicos, por exemplo: "Como assim?! Tem homossexual em quilombo?" e "No interior não tem gay, menos ainda em quilombo". Talvez isso se dê, por um lado, pela ausência de publicações sobre a temática, como já constatamos em outros momentos (Gontijo 2015; Gontijo \& Erick 2015), ou até mesmo pelas múltiplas formas que tomam o preconceito racial e o discriminação sexual presentes em nossas experiências sociais cotidianas, que sustentam a formulação cultural do corpo negro a partir da he- 
terossexualidade compulsória, do ideal reprodutivo (Rich 1983) e de um certo tipo de determinismo biológico, assim como o corpo camponês, o corpo indígena e o corpo interiorano estudado por um (ainda) pequeno número de pesquisadores (Ferreira 2006; Gonzalez 1984; Moutinho 2004a, 2004b; McCallum 2013). No imaginário construído sobre o quilombola e no Decreto de 2003, quilombola teria que ser forçosamente um sujeito negro. Junqueira (2012: 12) nota, por exemplo, que:

"Homens socialmente negros são em geral percebidos como "negros de verdade" se e somente se apresentarem determinados dotes "naturais", "próprios da raça", tais como: abundante virilidade - suposto atributo de uma acentuada masculinidade heterossexual - e habilidade para determinados ritmos, danças, esportes e trabalhos. Deles se espera que ajam segundo um igualmente "natural" pendor à malandragem, à indolência e à predação sexual."

Kilomba ([2010] 2016: 174), por sua vez, acrescenta que:

"No mundo conceitual branco, o sujeito Negro é identificado como o objeto 'ruim', incorporando os aspectos que a sociedade branca tem reprimido e transformando em tabu, isto é, agressividade e sexualidade. Por conseguinte, acabamos por coincidir com a ameaça, o perigo, o violento, o excitante e também o sujo, mas desejável - permitindo à branquitude olhar para si como moralmente ideal, decente, civilizada e majestosamente generosa, em controle total e livre da inquietude que sua história causa."
Neste sentido, parece se confirmar que há certa fetichização e/ou exotização do homem negro, seja este urbano, rural, interiorano e/ou etnicamente diferenciado, no imaginário formulado culturalmente sobre a raça no Brasil, politicamente instituído e reproduzido no cotidiano das experiências sociais. Além do mais, como geralmente o quilombola é visto como pertencente ao universo rural, tem-se uma idealização de seu corpo como sendo bíblico, sagrado e puro, não cabendo, pois, de modo algum, sua percepção enquanto corpo sexualizado, erótico e desejante (Ferreira 2006).

A partir dessas considerações acerca dos processos de folclorização das realidades quilombolas (e da fetichização dos corpos negros que estariam a elas atrelados) é que se justifica a necessidade de trazer ao debate e fomentar a produção de conhecimentos sobre as formas identitárias ou pertencimentos "desviantes" do padrão heterossexual compulsório, para além do contexto urbano brasileiro, como já apontamos em outro momento (Gontijo \& Erick, 2015).

Compartilharemos, a partir daqui, os relatos das experiências de Pedro e Dênis, ambos moradores de um quilombo situado no centro-norte do estado do Piauí, na Mata dos Cocais (o primeiro, 24 anos, manicure; e o segundo, 22 anos, quebrador de coco de babaçu), e de Beto e Alan, ambos moradores de um quilombo situado na parte leste do Arquipélago do Marajó, na Amazônia Paraense (o primeiro, 21 anos, estudante universitário, militante/ativista político que luta por melhorias das condi- 
ções de vida dos quilombos da região onde reside; o segundo, 19 anos, estudante do Ensino Médio, que sonha em sair do quilombo para morar na capital e fazer fluir seus desejos livremente). ${ }^{3}$ Esses relatos devem contribuir para mostrar como alguns marcadores sociais da diferença, tais como corporalidade, ruralidade, racialidade, etnicidade, gênero e sexualidade, são acionados situacionalmente. Assim, será possível propor um conhecimento alternativo complementar sobre os modos de vida de sujeitos quilombolas: eis a nossa proposta para iniciar uma conversa mais ampla sobre as múltiplas facetas das diversificadas realidades quilombolas no Brasil.

\section{DA MATA DOS COCAIS PIAUIENSE, PEDRO E DÊNIS: A DIFÍCIL GESTÃO DOS FLUXOS DE AFETOS.}

Conversando com uma colega de trabalho, na Universidade Federal do Piauí, Fabiano Gontijo ${ }^{4}$ foi informado de que, numa comunidade quilombola onde ela atuava junto com uma equipe de pesquisadores brasileiros e estrangeiros, havia um rapaz, Pedro, bastante "peculiar" pela maneira como cuidava zelosamente de suas unhas. $\mathrm{Na}$ comunidade, segundo a colega, todos diziam que ele era homossexual. Após conseguir a autorização das lideranças quilombolas da comunidade, Fabiano Gontijo partiu com dois estudantes para um breve período de observação direta e de conversa com Pedro, exatamente no momento em que estava acontecendo uma das festividades da região. Ao chegarem lá, os pesquisa- dores não tardaram em perceber que, além de Pedro, havia outros rapazes que não escondiam totalmente seu interesse afetivo e sexual por outros rapazes, como Dênis.

Pedro e Dênis são amigos de longa data: o primeiro, afeminado, mas se recusa em se "travestir totalmente de mulher", embora tenha as unhas sempre muito bem cuidadas, use batom "cor de pele" nos lábios, delineie as sobrancelhas e tenha cabelo "sempre bem tratado, alisado"5; o segundo, traveste-se para sair à noite, principalmente para ir às festas nas diversas comunidades quilombolas ou rurais da região, usa shorts e blusas femininas durante o dia, mas não usa maquiagem. Além da amizade, um segredo une os dois rapazes: a relação amorosa que Dênis mantinha com Antônio, o irmão mais novo de Pedro, "um homem mesmo, homem de verdade, ele come homem e mulher", segundo Pedro. O triângulo relacional estava montado.

A comunidade em questão está esparramada nas proximidades de uma fazenda do Século XIX em ruínas. Nessa fazenda, trabalhavam os ancestrais escravizados das 62 famílias (pouco menos de 350 pessoas) que atualmente compõem a comunidade. Na década de 1990, a comunidade se organizou para solicitar que os proprietários, que não apresentavam mais interesse econômico pela fazenda, a vendessem. No início da década de 2000, com recursos de uma entidade estrangeira e da Prefeitura, a fazenda foi desapropriada e a propriedade da terra foi concedida à associação de produtores rurais local em regime de comodato por tempo in- 
determinado. A certificação da comunidade como "remanescentes de quilombos" se deu logo em seguida, em meados da década 6 .

Entre palmeiras de cocais (babaçu, buriti e carnaúba ${ }^{7}$, etc) e árvores frutíferas, encontram-se as casas, em sua maioria de alvenaria ${ }^{8}$, e áreas de hortas e plantações. A comunidade margeia uma rodovia estadual que liga a sede de dois munícipios pequenos do norte piauiense. Se há um centro espacial na comunidade, talvez este seja o local onde se encontra a igreja católica e um tamarineiro que sombreia o largo. $\mathrm{Na}$ igreja, além dos rituais católicos, acontecem as principais reuniões de caráter político e administrativo local, momento em que as lideranças dialogam com os membros da comunidade. As famílias, em sua grande maioria, são agricultoras: dominam todo o processo de produção agrícola (arroz, feijão e milho são os principais produtos) e também de distribuição e comercialização dos produtos. Programas de transferência do Governo Federal complementam a renda familiar, sobretudo o Bolsa-Família. Uma atividade de grande relevância que merece destaque é a extração do óleo do babaçu, trabalho tradicionalmente realizado pelas mulheres (as "quebradeiras de coco"), para, por um lado, a fabricação de sabão, sabonete e cosméticos em geral para a comercialização e, por outro, o uso doméstico na culinária local; enfim, a casca do babaçu é usada para aquecer os fornos de barro, existentes em praticamente todas as residências?

Pedro tinha 24 anos no momento da entrevista. Nasceu em outra comunida- de rural (ainda não reconhecida como quilombo) e se mudou para a atual quando tinha 10 anos, com sua mãe e seu irmão, para morar próximo a um tio viúvo. $\mathrm{Na}$ outra comunidade, sua mãe deixou alguns filhos mais velhos e o marido. Pedro não tem notícias do pai no momento da entrevista. Com esse tio, Pedro e o irmão trabalhavam no roçado, enquanto a mãe extraía o óleo do babaçu, "quebrava coco". Ao concluir a quarta série do ensino fundamental, Pedro teve que abandonar a escola para se dedicar mais à lavoura. Ele conta que, desde essa época, começou a cuidar das mãos e das unhas. Com a morte do tio, a mãe de Pedro passou a cuidar também das três sobrinhas órfãs.

Alguns anos depois de chegar à comunidade, conheceu Lourival, um rapaz com quem manteve inicialmente uma relação de amizade muito forte, a ponto de se tornar em seguida uma relação amorosa fulminante. Pedro e Lourival se iniciaram sexualmente juntos, um com o outro, quando tinham 19 anos, embora Pedro já tivesse tido uma relação afetiva com um primo, quando tinham, ambos, cinco anos de idade. Pedro conta que: "sempre fui igual uma mulher do Lourival, nunca teve esse negócio de querer... fazer de outro jeito...". Quase todas as noites, os dois se encontravam, após as $22 \mathrm{hs,}$ para conversar e ir "pra outro canto, assim, mais escondido, assim, na beira de um caminho ou na beira do mato." Lourival começou a namorar também mulheres, o que deixou Pedro bastante entristecido. A decepção de Pedro aumentou ao saber que Lourival também 
ficava com outros rapazes: "pegava os rapazes por trás, nunca pela frente." Um dia, Pedro resolveu terminar o relacionamento, quando ambos estavam bêbados. Hoje em dia, são muito amigos, sempre se encontram nos bares e festividades, mas evitam ir para a "beira de um caminho ou na beira do mato".

Desde que deixou Lourival, havia pouco mais de um ano no momento da entrevista, Pedro resolveu conhecer outros homens da comunidade, sempre da comunidade: ele revelou que não gosta de sair com homens de fora da comunidade, por medo de ser levado para algum mato e ser assassinado e por medo "de pegar doença de gente que eu não conheço, principalmente que eu não sei com que mulher esses homens ficaram, se elas estavam doentes, sei lá", o que fez com que Pedro tivesse que se visibilizar enquanto homossexual na comunidade para que os outros homens percebessem seus interesses. Ao ser perguntado sobre como é para conseguir parceiros na comunidade, Pedro foi categórico:

“Às vezes tem uma brincadeira aqui, ali, tem uma festa acolá. Eu vou. Os meninos ficam me olhando, eu olho também, também a gente pisca o olho e vai pra fora, pra trás, pra beira do mato conversar. Depois a gente marca o lugar. Eu vou pro lugar, ele vai, a gente fica, assim, faz aquele negócio, né, aquele serviço daquela coisa lá, né. Mas tem vez que é no bar ali no caminho, ali na beira do caminho mesmo, no bar. Tem muito homem casado. A mulher não dá o que a gente dá, não dá. Eles vêm procurar nós. Mas eu só gosto de solteiro, só rapaz solteiro. Depois do Lourival, não quero mais namoro, não. Quero é aproveitar. Quero é brincar."

Pedro informou que havia outros rapazes afeminados na comunidade que "ficavam" com rapazes e homens casados. Ele se referia, em particular, a dois de seus amigos: um, Dênis, de quem falaremos mais a seguir; o outro, "um rapaz que ele também é homossexual, é o macumbeiro daqui, mora ali, eu vou pra casa dele e fico duas semanas lá às vezes; ele mora só, sempre só, gosta de homem casado, já quis que eu ia morar lá, não quero”. Esse último estava "ficando" com o ex-namorado de Pedro, o que não o impedia de manter a amizade com ambos. Havia ainda uma moça que "era um homem todo, todo, um macho", que vivia com Dênis. Essas quatro pessoas formavam o núcleo dos sujeitos transgressores aceitos pela comunidade.

Pedro era conhecido na comunidade por ser o facilitador de relacionamentos: nas festas e bares, quando alguém estava interessado em "ficar" com alguém, bastava pedir a Pedro "arranjar o encontro" que ele o fazia com todo o prazer, para homens que queriam "ficar" com mulheres, assim como para homens que queriam "ficar" com outros homens (Pedro não se lembrava de mulheres que o tivessem pedido para ajudar a marcar encontros com outras mulheres). Pedro achava que era por isso que ele era visto como uma pessoa amável e sociável por todos na comunidade. Durante os dias que os pesquisadores ficaram lá, só ouviram elogios a respeito de Pedro. 
Mas, se todos sabiam da homossexualidade de Pedro e, aparentemente, o respeitavam, será que ele nunca tinha sofrido alguma forma de preconceito? Ele contou que sim, antes de um fato curioso. Havia uma moradora, Dona Marinalva, que, segundo ele, gostava de difamá-lo, exortando para que as mães não deixassem seus filhos se aproximarem de Pedro para "não virar[em] viado". Pedro estava sempre acompanhado de Dênis, nesse momento de sua vida. Os dois saíam juntos, de mãos dadas, pela comunidade; Dênis, às vezes, travestido. Isso só aumentava a difamação por parte de muitos moradores, incitados por Dona Marinalva. A filha dela era agente de saúde. Um dia, uma médica veio visitar a comunidade. Pedro e Dênis resolveram aproveitar a passagem da médica para fazer uma espécie de denúncia junto à respeitada profissional da saúde, já que os difamadores diziam que eles eram "doentes". A médica lhes disse, em frente a outros moradores e à filha de Dona Marinalva, que eles não eram doentes e que estavam "mais saudáveis do que muita gente lá”. A notícia se espalhou rápido e chegou aos ouvidos de Dona Marinalva, que, desde então, nunca mais disse nada - e passou a ser muito malvista pelos moradores, como os pesquisadores puderam perceber durante as curtas estadias. Por outro lado, Pedro disse que os rapazes gostavam de "tirar brincadeira", mas que ele gostava, pois via nisso uma das facetas do jogo de sedução e também "tirava brincadeira" com os rapazes - isso, para ele, não era preconceito.

Para Pedro, "a melhor coisa do mundo, é ficar em casa, cuidando da casa, da minha mãe velhinha, fazendo comida pra ela". No momento da entrevista, Pedro não trabalhava mais na lavoura, nem sua mãe quebrava coco. Seu irmão continuava trabalhando na lavoura, mas de agricultores da região, ganhando diárias - chegou a ir para Brasília para "tentar a vida", mas não gostou e voltou. Quando não estava em casa ou conversando com outros moradores ("Adoro conversar, meu Deus, adoro! Posso passar a vida inteira na frente de casa conversando ou ali no tamarineiro, é bom demais!", afirmou Pedro), Pedro estava cuidando da quadrilha junina da comunidade, como coreógrafo, ou jogando futebol. Pedro era reconhecido como um dos melhores jogadores da comunidade, praticando quase todos os dias: "Só tomo cuidado pra ninguém quebrar minhas unhas, nunca!" Os pesquisadores puderam vê-lo jogando e também tiveram a oportunidade de ver alguns membros da quadrilha indo à sua casa para provar as roupas (dois deles, homossexuais que se vestem com roupas de personagens femininos da quadrilha, segundo Pedro, mas que moram em outra comunidade quilombola próxima).

Embora Pedro já tenha visitado outras cidades do interior do Piauí e já tenha ido algumas vezes à capital, Teresina, para participar de umas edições da Feira Piauiense de Produtos da Reforma Agrária e de Comunidades Quilombolas (FERAPI), ficou claro que ele não tinha nenhum interesse em sair da comunidade para ir morar na "cidade grande". Por que?

"Eu achei ótima [Teresina], Ave 
Maria, para mim, foi bom demais [a última ida à capital]! Andei muito, só andando, vendo tudo. Se eu passar dois, três dias, nunca me dou mal; mas para um ano, dois anos, não dá, nunca, não gosto de cidade... Não quero viver longe da minha mãe, não quero. Nem longe daqui, das brincadeiras, as festas.”

Pedro se considerava quilombola "porque eu sou negro, sou mais claro que meu irmão, mas sou negro, a gente veio de escravo, a fazenda tinha escravo, era tudo parente nosso, os fazendeiros deixaram a fazenda, mas nós ficou tudinho aqui, nós somos quilombola descendente de escravo."

O irmão de Pedro, Antônio, também afirmava seu pertencimento quilombola. Um "quilombola macho". Quando Pedro contou aos pesquisadores que Dênis e seu irmão "tinham um caso", criou-se um interesse em conversar com Antônio. Pedro disse que, um dia, estava "ficando" com um rapaz em sua casa, enquanto sua mãe havia ido à sede do município e seu irmão, estava trabalhando. Mas, seu irmão voltou mais cedo e viu os dois na cama. Seu irmão esperou que terminassem e lhe disse que era para tomar cuidado para a mãe não saber daquilo. Pedro esperava uma reação mais agressiva por parte de seu irmão. Algumas semanas depois, quando Dênis estava passando uns dias em sua casa, Pedro viu os dois se relacionando sexualmente. Dênis e Antônio perceberam que Pedro os havia "descoberto", mas fizeram como se nada tivesse acontecido. Antônio era um dos rapazes da comunidade conhecido por manter relações sexuais com outros rapazes, principalmente com seu amante preferencial, Dênis, mesmo tendo namoradas. Desde então, Pedro, Antônio e Dênis viviam numa espécie de triângulo relacional que gerenciava os ditos e os não-ditos dos três.

Quanto a Dênis, tinha 22 anos no momento da entrevista. Nasceu numa outra comunidade rural próxima à de Pedro, que está passando pelo processo de reconhecimento como comunidade quilombola. Desde muito cedo, ainda criança, se sentia atraído por homens e se feminilizava: brincava com bonecas, se maquiava e colocava roupas de suas três irmãs. Sua mãe era quebradeira de coco de babaçu e Dênis ia quebrar coco com suas irmãs, sua mãe e as mulheres da comunidade. Nunca trabalhou na roça com os homens. Foi à escola até a primeira série do ensino médio, mas abandonou a escola porque achava cansativo ter que ir à sede do munícipio para ter aulas, assim como Pedro. Durante sua infância, seus pais decidiram migrar para o Maranhão. Alguns meses depois, seu único irmão decidiu voltar para o Piauí, indo morar na comunidade de Pedro, onde residia sua noiva. Dênis foi morar com o irmão, bem em frente à casa de Pedro. Assim começou a amizade com Pedro. Juntos, eles seduziam os homens da comunidade, vestindo-se com roupas femininas e se maquiando. Seus pais não se adaptaram muito bem ao Maranhão e resolveram voltar ao Piauí, indo morar na mesma comunidade onde moravam antes. Dênis ficou morando um pouco na casa de seu irmão e um pouco na casa de seus pais. Depois, passou a morar também na casa de Pedro, quando 
se apaixonou por Antônio.

Até os nove anos de idade, Dênis brincava de "homem e mulher" com os meninos de sua comunidade: "eu sempre era a mulher deles". Um de seus tios, casado com a irmã de sua mãe, teve relação sexual anal com Dênis quando ele tinha nove anos. Os dois mantiveram um relacionamento durante alguns meses, mas Dênis afirmou que era muito doloroso para ele. "Aí, eu pequei esse pecado um pouquinho", disse, referindo-se à descoberta de sua homossexualidade, e continuou: "tem gente que acha que é sem-vergonhice da gente, mas não é; eu sempre fui assim; já vem na sina da pessoa, que a gente traz esse dom, né".

$\mathrm{Na}$ escola e na comunidade, as pessoas comentavam sobre os trejeitos de Dênis. Um dia, sua tia e sua mãe estavam quebrando coco com outras mulheres e veio à baila o assunto sobre a homossexualidade do adolescente. Num primeiro momento, sua mãe foi categórica, dizendo que não aceitaria que seu filho fosse homossexual. Mas, ao longo da conversa, foi convencida por sua irmã de que um filho deve ser amado de qualquer forma, mesmo que seja homossexual. Ao voltar para casa, Dênis é surpreendido por sua mãe, que lhe pergunta se ele era mesmo homossexual. Aos trezes anos, Dênis confirmou a sua homossexualidade e, desde então, passou a ter o apoio incondicional de sua mãe. Seu pai soube algum tempo depois, mas se mostrou indiferente, dizendo que a vida era do filho e que ele fazia o que achasse melhor. Sua mãe começou a comprar roupas mais femininas para Dênis e todo o instrumental de feminilização: "nunca gostei de saia, vestido, nunca; gosto é de shortinho, blusinha, só, calcinha pequena".

Ainda adolescente, Dênis começou a trabalhar em "casa de família, de doméstica”. Cozinhava e limpava a casa, além de cuidar de filhos pequenos dos seus patrões. Sua fama de cozinheiro se espalhou pela região e, ainda hoje em dia, Dênis ganha algum dinheiro fazendo comida sob encomenda para festas e recepções. Também é atuante nas quadrilhas juninas locais, junto com Fernando. Ele sempre se fantasia de mulher e consegue ganhar algum dinheiro em concursos de quadrilhas e de beleza, miss gay etc.

Dênis fez uma análise bastante interessante das diferenças entre os homossexuais das sedes municipais e os da comunidade onde mora Pedro. Ele contou que não gostava muito de se envolver com homossexuais das cidades, pois eram "trambiqueiras, falsas, mentirosas, e dão encima de tudo quanto é homem, não respeitam ninguém! Elas querem ser mais do que a gente que é da roça! Elas acham que são melhores!" Na comunidade onde Pedro reside, Pedro, Dênis e um outro homossexual afeminado ajudavam um ao outro a "apanhar macho, pegar homem mesmo". Não haveria ali "concorrência” ou disputa por parceiro. Já nas cidades da região e em sua comunidade, Dênis afirmou que havia muita concorrência. Ele contou a história de um rapaz que se mudou da cidade para sua comunidade e que estava "atacando tudo quanto é macho, lá, tudinho!” Esse rapaz, segundo Dênis, ia para a 
roça atrás dos homens:

"Ela quer ser a poderosíssima, corre até atrás dos homens nos matos onde os homens vão trabalhar, trabalhar na roça; quando ela vê um homem saindo com uma foice no ombro, ela papoca atrás, eu só vejo notícia dela, lá, forçando homem casado a ficar com ela, só os homens casados! Todo dia, todo dia tem história dela!"

Para Dênis, os homens casados não tinham interesse nesse rapaz, somente os solteiros. Dênis concluiu que, assim como na comunidade de Pedro, por mais que haja homem casado interessado em homossexuais, são os mais jovens que mais "ficam" com homossexuais para se iniciar sexualmente e acumular experiência, antes de se casarem com as moças das comunidades.

Assim, parece se confirmar, com essa análise de Dênis, que haveria uma espécie de cálculo complexo que equilibraria a tensão sexual e regularia os relacionamentos localmente: homossexuais são aceitos, se - e somente se - forem afeminados, passivos, performatizarem o gênero feminino (Butler, 2003) e substituírem temporariamente as moças (que devem "se preservar para o casamento") enquanto parceiros sexuais de jovens rapazes ativos (o que remete até certo ponto ao modelo hierárquico de gênero proposto por Fry, 1982). Assim, não faltam parceiros para os homossexuais, nem para os rapazes considerados heterossexuais e, enfim, as moças não são assediadas. Mas, não pode haver um número muito grande de homossexuais para que o sistema funcione de maneira a manter um equilíbrio quase que homeostático, nem pode haver relacionamentos amorosos fixos (e de exclusividade absoluta, monogâmicos) entre homossexuais e heterossexuais.

O único namorado que Pedro teve, Lourival, se apaixonou por ele, o que infringe a regra dos relacionamentos locais. Por isso, quando terminaram, Lourival não conseguiu se casar com uma moça e teve que "se juntar" a uma mulher mais velha, viúva, com quem residia no momento da entrevista. Antônio, o irmão de Pedro, teve que romper o relacionamento com Dênis, quando percebeu que já era hora de procurar uma moça para se casar. No momento da entrevista, ele estava namorando. Já na comunidade onde os pais de Dênis residiam, a chegada de um homossexual citadino estava ameaçando o fluxo dos relacionamentos afetivos, o que fez com que Dênis resolvesse se mudar para a comunidade de Pedro, onde "os homossexuais se ajudam, não tem essa concorrência" e os afetos fluem tranquilamente. Assim parecia funcionar, ali, a gestão dos fluxos de afetos.

\section{DA AMAZÔNIA PARAENSE, BENTO E ALAN: A DIFÍCIL GESTÃO DA VI- SIBILIDADE.}

Bento é discente de um curso de graduação interdisciplinar da Universidade Federal do Pará e uma jovem liderança quilombola. Bruno R. C. Domingues ${ }^{10}$ conheceu Bento durante uma pesquisa que estava realizando no Arquipélago de Marajó para um outro projeto. Fizeram parte da mesma equipe, portanto, 
Bruno poderia pressupor que haveria ali uma certa facilidade para se aproximar de Bento e falar sobre sexualidade. Ao serem apresentados um ao outro, durante a primeira atividade do projeto, Bento disse que era quilombola, que participava ativamente da luta quilombola e que sua comunidade era próxima de onde Bruno e a equipe estavam pesquisando.

Como, então, Bruno "reconheceu" a homossexualidade de Bento? Bento infringia alguns padrões socialmente estabelecidos sobre como homens e mulheres falam e gesticulam ou como homens e mulheres devem se vestir ou como devem se comportar, portanto, Bruno viu em Bento um "igual", um "mesmo". Mas, como explicar, durante uma pesquisa sobre "ecologia de saberes" 11 , que Bruno gostaria de entrevistá-lo para outra pesquisa, relacionada a gênero e sexualidade? Bento sequer havia se identificado enquanto homossexual, mas, dado sua performance de gênero (Butler, 2003), Bruno já havia percebido que, sendo homossexual ou não, ele seria um sujeito em potencial para a pesquisa sob a coordenação de Fabiano Gontijo, sobre as experiências da diversidade sexual e de gênero em contextos rurais e situações etnicamente diferenciadas e quilombos.

Mais tarde, a equipe do projeto se reuniu para dividir as tarefas e, por conseguinte, montar as equipes, compostas por oito pessoas. Seriam formadas, portanto, quatro duplas e, coincidentemente, Bento viria a ser o parceiro de Bruno na dupla. Durante as longas caminhadas pela comunidade onde estavam, Bruno e Bento costumavam con- versar sobre assuntos diversos, desde o currículo dos seus cursos de graduação, passando pela situação política do País e os impactos do golpe jurídico-político-midiático ocorrido em 2016 sobre a situação das pessoas negras - afinal, Bruno também compõe o movimento negro paraense e, assim, aproveitaram para conversar sobre como articular movimentos de negros urbanos com os movimentos quilombolas e demais negros rurais -, até assuntos de cunho mais pessoal, família, amigos, relacionamentos amorosos, entre outros, mas em nenhum momento Bento tocou no assunto da sexualidade, e optou-se por não conduzi-lo a tal assunto - pelo menos, por enquanto.

Em alguns momentos, perceberam-se falas que pareciam indícios de formas de preconceitos de cunho sexual ou de gênero, quando Bento conversava com algumas pessoas da comunidade, geralmente pessoas mais velhas que têm contato direto com a família de Bento; então, em conversas com elas, percebia-se ali um "outro Bento", com voz firme e mais grossa, um modo de agir diferente, com falas que até reproduziam certos preconceitos. Ficou claro que havia uma preocupação, por parte de Bento, enquanto uma jovem liderança quilombola, em reforçar a masculinidade. Contudo, assim que os dois se afastavam daquelas pessoas, voltavam à configuração anterior de interação. Estaria Bento acionando um "armário", quando interagia com pessoas próximas à sua família? Segdwick (2007) sugere que uma pessoa nunca se livra totalmente de seus "armários", por mais "desconstruída" que seja a 
pessoa. Ao voltarem para a casa em que estavam hospedados, falaram, enfim, sobre a pesquisa de Fabiano Gontijo e Bruno perguntou se Bento tinha interesse em colaborar. Eis a resposta recebida: "Sim, mas só quando tu voltares! Aqui tem muita gente e não quero que eles escutem o que tenho pra te dizer, tipo, sei que vais publicar, e eles vão ler, mas vou ficar com vergonha se alguém além de ti me ouvir falando."

Bruno retornou a Belém e Bento, à sua comunidade. Eles se adicionaram como amigos virtuais no Facebook e por ali mantiveram contato. Vez ou outra, Bento o chamava para o bate-papo virtual, perguntando-lhe sobre quando voltaria ao Marajó; dizia estar ansioso para a entrevista, porque nunca ninguém o tinha entrevistado, exceto para processos seletivos, e que ele tinha interesse em falar um pouco sobre o assunto. Bruno lhe disse que o retorno estava previsto para maio de 2016, e que, nesta ocasião, poderiam marcar a entrevista.

$\mathrm{Na}$ data prevista, Bruno retornou à comunidade quilombola, novamente com a equipe do projeto anteriormente citado. Ficou hospedado na mesma casa. A entrevista aconteceu na última noite da pesquisa de campo, que deveria ser a noite de folga da equipe (poderiam dormir mais tarde, ver filmes, ouvir música...). Enquanto uma parte da equipe aproveitava para conversar e depois assistir filmes, Bento e Bruno foram para um cômodo da casa que estava servindo de quarto para o grupo de pesquisadores.

Bruno iniciou a conversa explicando novamente o porquê da entrevista, do que tratava a pesquisa, que não faria perguntas diretas, conversariam mais ou menos livremente para que não fosse criado um tipo de formalidade prejudicial à fluidez da conversa, e para que ele não ficasse nervoso. Em seguida, Bruno perguntou como Bento se afirmava, ao que ele respondeu peremptoriamente: “Gay!”. Conversaram acerca das primeiras experiências do entrevistado que o permitiam se definir como "gay": "O primeiro homem que eu fiquei foi meu primo, ele tá morando em outra comunidade agora e tem uma filha. Ele não se aceita, sabe? É preconceituoso. A família desconfia de mim e dele, a comunidade também, só que a gente nunca falou nada pra ninguém."

A forma como Bento iniciou-se sexualmente não ocorreu como se observa nos escritos sobre iniciação sexual em Belém (Silva Filho 2013), tampouco como no Rio de Janeiro ou Paris (Bozon \& Heilborn 2006), ou seja, não houve uma procura ou um querer iniciar-se para se incluir em grupos de sociabilidade específica, segundo o interlocutor, mas aconteceu de forma espontânea e, de certo modo, inesperada, assim como observamos com os interlocutores piauienses mais acima:

"A gente foi pescar, daí, a gente estava no bote do meu pai, eu estava pilotando. Aí, começou a chover e ele disse pra gente tomar banho de chuva, depois disse 'se for pra gente tomar banho é melhor sem roupa aqui fora do que dentro do bote', daí, a gente foi... E eu me abaixei, ele pegou na minha bunda, e eu disse 'não', aí, depois eu olhei 
pra ele e vi que o 'coiso' dele estava assim... Duro né?! Aí, eu perguntei se ele tinha camisinha, e ele disse que estava no bote, e aconteceu lá mesmo. A gente ficou um tempo, mas tem mais de um ano que a gente não fica... Desde que eu comecei a universidade."

Bento tem muitas histórias sobre os relacionamentos com rapazes da comunidade, que não se afirmam enquanto homossexuais, durante as atividades de trabalho ou de lazer na mata, assim como nosso interlocutores piauienses. ${ }^{12}$ Percebe-se, portanto, que a mata, longe das vilas, sítios ou caminhos da comunidade e demais espaços de trabalho no meio rural parecem ser espaços privilegiados (os "guetos da ruralidade"? $\left.{ }^{13}\right)$ para as relações afetivas e sexuais entre jovens homens, em meio a encantados e visagens, entes sobrenaturais típicos do cenário amazônico:

"Eu fui com um homem da minha comunidade, casado, pegar marajás ${ }^{14}$, aí chegou lá, ele perguntou se eu queria transar. E a gente "ficou" lá mesmo. Também teve outro casado, quando a gente tava pegando açai ${ }^{15} \ldots$ Mas aí, tinha muita gente, era um grupo de homens da comunidade... Aí, ele se afastou e me chamou, aí, perguntou se eu queria e eu disse que sim. A gente entrou mais pra dentro do mato e aconteceu."

É comum que homens casados busquem relações extraconjugais com rapazes na comunidade de Bento, assim como na comunidade piauiense citada mais acima. Sobre isso, ele nos diz: " $E$ ' normal, isso, na minha comunidade; eu mesmo já fiquei com muito homem casado de lá. Eles gostam de corpo feminino, bunda grande... Mas as mulheres, às vezes, não faz o que a gente faz, né?! Daí, eles procuram a gente. Prefiro os solteiros."

Tais dados remeteriam à "heterossexualidade como modelo social", (Miskolci 2009: 6) ou à "heterossexualidade compulsória" (Rich 1983), mas com fortes nuanças - já que nossa amostra ainda é muito reduzida e nos impede de propor generalizações perigosas. Afinal, tal como apontava Foucault (2001), o sexo sempre carregou a verdade por trás dos seres humanos; logo, a ação de manterem casamentos heterossexuais, e, ao mesmo tempo, vivenciarem práticas sexuais com pessoas consideradas como sendo do mesmo sexo ainda se afirmando como heterossexuais reforçaria que tal afirmação nada mais seria do que uma forma de garantir a hegemonia das relações de poder vivenciadas no cotidiano. Isso vale também para a realidade piauiense relatada mais acima. Mas, os homossexuais teriam que ser afeminados, como vimos com Pedro e Dênis, embora afeminados de um certo jeito.

Bento relatou que somente um rapaz em sua comunidade disse abertamente ser homossexual. Ele percebeu que, nas comunidades quilombolas, existia muitos jovens homossexuais ou bissexuais, mas que, dado o medo, não pretendiam "se assumir" - Bento, aqui, usou as categorias comumente usadas nos grandes centros urbanos, categorias médico-científicas, como "homossexual", "bissexual" e até mesmo "gay", mostrando, assim, seu trânsito entre rural e urbano e a maneira como 
usa categorias de ambos os contextos, dando-lhes significados híbridos, que pertencem a um terceiro contexto, intersubjetivo. Disse ainda que não pretendia contar para familiares e demais pessoas sobre sua sexualidade, principalmente por ter uma trajetória política na comunidade. Por isso, a difícil tarefa de gerenciar o dizível e o indizível e de negociar os significados híbridos:

"Se eu gostar de alguém quando eu tiver morando sozinho, ele vai morar aqui comigo, mas eu não vou dizer para ninguém que a gente é casado, a gente vai viver como amigos que moram juntos, mas não como casal. Muita gente me conhece, eu sou representante da comunidade em muitos lugares, não vou falar nada, não."

Bento é estudante universitário em uma cidade do interior do Pará que sofreu um boom populacional em razão de um grande projeto de desenvolvimento que está sendo implantando na região. A cidade abriga pessoas de diversas localidades do Brasil, tomando um certo ar cosmopolita, como acontece(u) com diversas cidades do interior do Pará ao longo das últimas décadas. Isso faz com que Bento se sinta mais à vontade para se expressar enquanto homossexual nessa cidade durante os meses de aulas. Lá, Bento vai a festas, usa maquiagem e roupas femininas, enfim, expressa "seu" gênero como bem lhe convém: "Lá eu sou mais livre, uso bermuda de mulher, uso maquiagem, vou para universidade de batom... E meus amigos daqui que estudam lá sabem que eu sou gay, mas eles guardam o segredo quando a gente volta pra cá".
Novamente, pode-se pensar aqui na "epistemologia do armário", quando Sedgwick nos diz que "mesmo num nível individual, até entre as pessoas mais assumidamente gay há pouquíssimas que não estejam no armário com alguém que seja pessoal, econômica ou institucionalmente importante para elas". Bento nos fala ainda sobre os sujeitos com quem se relaciona na cidade onde estuda: normalmente, são pessoas "com uma mente mais aberta", que "convidam para almoçar em casa" e "são brancas", embora o interlocutor diga preferir rapazes negros. Qual a diferença?

"Tem diferença, sim, os caras do quilombo e os caras de lá. Lá, eles são mais tranquilos e sem tanto medo de serem pegos. Aqui, os meninos do quilombo têm medo de serem gay e alguém pegar eles durante o sexo. O sexo é sempre pensando 'vai chegar alguém'. [...] Os caras que eu fico por lá, e por Belém também normalmente são brancos, mas eu prefiro os negros. Os brancos só dão atenção antes do sexo, os negros dão mais atenção durante o sexo. Quando eu tô com um negro, é algo mais igual, sabe? Quando eu tô com um branco, é diferente, porque eles são mais 'te vira, tu que tem que fazer tudo'."

Ao distinguir a relação sexual entre homens brancos e homens negros, o discurso do interlocutor parece reforçar o debate sobre a sexualização da raça e/ou a racialização do sexo (Miskolci 2008) e sobre a exotização/fetichização do "ser quilombola" e, portanto, a fetichização da diferença. Segundo 
Miskolci (2012) o Brasil se constituiu a partir de privilégios da branquitude, o que não exclui o fator sexualidade. Desde as relações coloniais, o negro foi considerado como o cativo disponível para servir ao senhor branco. Mesmo com a Abolição da escravatura no Brasil, em 1888, esta situação não foi totalmente modificada - talvez tenha sido até complementada, agora com um forte viés de classe -, afinal, “o poder não é uma instituição e nem uma estrutura, não é uma certa potência de que alguns sejam dotados: é o nome dado a uma situação estratégica complexa numa sociedade determinada" (Foucault 2015: 101). Portanto, as formas como as relações raciais se deram no Brasil pós-Abolição mantiveram a hegemonia social, racial e econômica da população branca, garantindo privilégios sociais e estabelecendo novas relações de dominação, ainda que de forma velada, configurando o "racismo à brasileira" (o branco não se percebe como racista, uma vez que associa o racismo somente aos aspectos físicos e, logo, objetivos e concretos).

Após conversar sobre mais alguns temas, Bruno e Bento encerraram a conversa/entrevista. Ao final, o interlocutor disse que gostou de participar e que achou que seria algo mais complicado de se falar. Passemos, enfim, à conversa/entrevista com Alan.

Bruno conheceu Alan de uma maneira um tanto quanto curiosa. Bruno ainda não sabia muito bem como poderia se aproximar de seus potenciais interlocutores para pedir-lhes que lhe concedesse um momento de sua atenção para falarem de suas vidas. Então, Bruno percebeu, enquanto fazia a pesquisa de campo de maio de 2016 (durante a qual procedeu à conversa com Bento), que uma de suas colegas de pesquisa, Maíra, estava hospedada na casa de uma das pessoas mais dinâmicas $\mathrm{da}$ comunidade, que conhecia toda a comunidade (todos paravam em sua casa para colocar a conversa em dia, pois lá também funcionava um bar). Então, Bruno pediu para que Maíra comentasse com alguém da casa que ele gostaria de conversar com "homens homossexuais" para uma outra pesquisa. Bruno contou com a sorte, torcendo para que a notícia fosse espalhada por toda parte.

Quando Maíra retornou a Belém, depois do retorno de Bruno, tinha muitos recados para o colega:

"Bruno, no próximo campo, tu já tens como entrevistar algumas pessoas. Falei lá na casa da Jô e eles conhecem, sim, [homossexuais] e te apresentarão no próximo campo. E tem outros nas comunidades vizinhas. Tem uma travesti também, eu estava na festividade e a vi, ela estava no mastro das mulheres. Os homens diziam que ela tinha que ir pro dos homens, as mulheres foram lá e disseram que não, que ela era mulher e tinha que permanecer ali, foi tão lindo!"

Bruno voltou a campo em meados de julho e tentou contato com alguns jovens, dentre os quais, Alan. Contudo, não obteve muito êxito. $\mathrm{O}$ futuro interlocutor estava inseguro, se esquivava e nunca comparecia aos locais e horários que ele mesmo marcava para o encontro, embora Bruno tenha explicado que se tratava 
de uma pesquisa com garantia de anonimato e que ele poderia ficar tranquilo, pois seus dados pessoais não seriam divulgados. Bruno acabou tendo que retornar a Belém, frustrado, sem tê-lo entrevistado.

Em setembro de 2016, Bruno voltou a campo. Num dos últimos dias, pôde, enfim, se concretizar a conversa com Alan. O interlocutor esclareceu sobre a razão de não ter ido aos encontros anteriores: "Eu perguntava pra Jô 'O que que esse homem quer comigo? $\mathrm{Ai}$, será que vou ter que responder algo difícil?’ e ela dizia que não, mas eu ficava meio assim [balançando a cabeça para demonstrar falta de confiança]..."

A entrevista aconteceu no bar situado em frente à casa de Jô, na comunidade em que Alan mora. Bruno contou com a ajuda de um outro estudante do curso de Ciências Sociais da UFPA que, na época, o acompanhava em campo para definir o tema de seu trabalho de conclusão de curso. Eles se sentaram em cadeiras ao lado de um bilhar, os estudantes um ao lado do outro e Alan, em frente aos dois. Tomavam café e comiam biscoitos enquanto a conversa fluía.

Bruno iniciou explicando do que a pesquisa tratava, de sua importância e que os dados pessoais de Alan não seriam divulgados. Disse-lhe que seria iniciada uma conversa, permeada de poucas perguntas, e que, se em algum momento o interlocutor se sentisse desconfortável ou achasse que as perguntas estavam sendo invasivas, que poderia pedir a interrupção da conversa.

Alan se afirma como "homossexual" desde 2014. Nunca contou para a sua família, pois não precisou: as vizinhas contaram. Ainda assim, sempre que sua mãe o perguntava, ele ainda nega:

"Minha mãe sabe e me pergunta, mas eu nego. Teve um tempo também que eu estava na $6^{a}$ série $e$ mamãe me perguntou se eu sentia atração por homem, e eu disse que não, peguei minha mochila e fui embora pra escola. Ela sabe... Disse que vai contar pro meu pai, ele mora em outra cidade, vem pra cá só no Natal... Uma pessoa aqui da passagem contou pra minha mãe que meu namorado veio da cidade pra minha festa de aniversário aqui, e ela disse que quando o papai chegar vamos conversar sério. Aqui o meu nome roda, dizem que eu tenho macho, que eu tenho marido, tudo mentira. Quando o papai chegar, aí, eu não sei, né?! Aí, eu vou ter que falar a verdade, não dá pra negar o tempo todo."

O interlocutor sempre negou quando sua mãe o perguntava acerca de sua sexualidade para poupar a família, pois, segundo ele, todos dizem que na família dele não têm homossexuais, nem "espaço pra gay".

"Eu sinto vergonha, a minha família sempre diz que não tem gay na nossa família, só que já têm três comigo, mas meus primos são bem mais discretos, elas nem desconfiam. Pra eles, vai ser uma vergonha enorme, mas gosto não se discute, né?! E eu tenho vergonha da sociedade, também, porque a partir do momento que tu te assumes como gay, a sociedade te olha com outros olhos."

Alan não entrou em detalhes acerca de 
sua iniciação sexual, disse que foi "normal, com muita conversa, tem que ter conversa, né?! Não pode ser nada forçado". Disse que já ficou com rapazes da comunidade, mas que não se sente muito à vontade para isso, pois, segundo ele: "Os caras daqui que são solteiros ficam contigo e espalham pros amigos, daí, depois que todo mundo já tá sabendo, eles dizem que é mentira. Teve um que é casado e que eu tive que ir lá falar com a mulher dele, dizer que era mentira, fofoca."

Uma consideração importante a se fazer é que o "ser homem" na concepção de Alan, tem a ver com: "homem, pra mim, é o que anda ${ }^{16}$ com mulher, não o que anda com homem; tem homem que até fica ${ }^{17}$ com outro homem, mas tem uma mulher." Sendo assim, a imagem do homem é construída sobre os padrões heteronormativos, em que só é "homem de verdade", "macho", aquele que constitui relações heterossexuais permanentes, mesmo que esporadicamente e sem se afirmar como tal, tenha relações sexuais provisórias com outros homens, mais ou menos como bem nos apontaram Fry (1982) e, depois, Parker (1991). Alan também tem uma forma peculiar de classificar "atividade" e "passividade" no relacionamento entre homens. Segundo o interlocutor: "O passivo, ele não pode ser atirado, ele tem que ser calmo, ser paciente e esperar. $\mathrm{O}$ ativo é quem chega e já chama, puxa pra dançar, convida pra transar, isso é o dever dele." Isso se repete na realidade rural piauiense relatada acima.

Neste sentido, as noções de "atividade" e "passividade" aqui também se constituem sob os moldes da heteronormatividade, uma vez que é como se o "passivo" precisasse esperar e ser submisso ao "ativo", ou ao "macho de verdade", num sistema onde tudo o que remete ao "não homem" é automaticamente tido como "abjeto" (Butler, 2000) e que necessita obedecer às hierarquias. Mas, há negociação entre os sujeitos, até mesmo para definir as fronteiras da abjeção e as posições na hierarquia.

$\mathrm{O}$ interlocutor falou acerca de preconceito e racismo no Marajó, além de fofocas, tema que, aliás, aparecia em quase todos os pontos que Bruno colocava durante a conversa, como se pode observar nos trechos a seguir:

"Aqui na comunidade ninguém gosta de se comprometer. Se eu estou namorando contigo, por exemplo, e a gente se expõe, isso vai virar um fato. E aqui ninguém gosta de ver os seus problemas, né?! Só gostam de falar dos outros. Mas, quanto mais eles falam, quanto mais eu faço! A vida é só uma, temos mais que aproveitar."

"Lá na minha escola ia ter o concurso de Mister. Daí, eu nem queria, mas começaram a falar meu nome, e eu fui. Aí, chegou um outro menino lá de outra turma, que também estava concorrendo. Ele é branco, alto, e disse que ia me bater, que eu era uma bicha "muito por fora" $18 \mathrm{e}$ que ele não gostava de mim. Teve outro menino também que, eu estava passando no corredor da escola, e ele me xingou; e eu voltei, dei de porrada nele. Porque antes eu não falava nada, mas agora, eu brigo e muito!"

Alan também relatou sobre o racis- 
mo em relacionamentos com pessoas brancas, mas não quis aprofundar esse assunto. Bruno verificou que há uma tendência em Alan a se relacionar com homens brancos e de fora do contexto do quilombo, assinalando, portanto, para o quanto as relações amorosas e afetivas em geral ainda se baseavam em idealizações e padrões de beleza externos ao contexto quilombola. Alan disse: "Não que eu tenha preconceito, mas eu prefiro, assim, gosto de gente clara do olho claro; meu ponto fraco são os morenos $^{19}$; mas, pra namorar, tem que ter olho claro mesmo." Segundo Silva Filho (2013: 103) "a conquista de um/a parceiro/a de outra cor/raça seria também uma forma de mostrar presteza na arte da conquista ou evidenciar o quanto se é desejável, por sua condição racial, às outras raças".

Alan continuou a falar sobre seus "gostos" e sobre "pessoas de fora da comunidade" e disse que nas festividades sempre encontrava rapazes das cidades, que procuravam sexo com rapazes do quilombo. Segundo ele:

"Eles sempre vêm pras festividades. No Círio mesmo, no sábado, que vocês estavam lá na festa, até. Eu contei seis homens que me procuraram, querendo sexo. Primeiro eles ficam dançando e te olhando, depois mordem os lábios, depois levantam a camisa, mostrando que têm interesse, né?! Depois, eles te procuram."

Novamente, há de se remeter à fetichização da diferença, quando rapazes externos ao meio quilombola vão até lá apenas com finalidades sexuais. Giraldo, Arias e Reyes (2007), ao anali- sar a construção da masculinidade em Cali, apontaram para essa fetichização, quando verificaram que comumente pessoas de classes altas se sentiam atraídas sexualmente por homens da periferia, assim como Fry já o havia notado em suas pesquisas (Fry, 1982). Pode-se, portanto, traçar a mesma linha de pensamento acerca do aumento do número de homens homossexuais da cidade em busca de relações afetivas e sexuais nos quilombos durante as festividades locais.

Alan sonhava em, um dia, casar-se com um homem e sair do quilombo, mudar-se para Belém, principalmente por se sentir incomodado com as fofocas que correm sobre ele na comunidade. Desejava ser médico e encontrar alguém que não sentisse vergonha dele, nem de suas carícias, o oposto de seu último namorado - branco e citadino. Nota-se, assim, tanto com Bento como Alan, a difícil tarefa de gerenciar a visibilidade dos afetos.

\section{PERSPECTIVAS}

Os estudos sobre realidades quilombolas, assim com os estudos rurais e os estudos de gênero e sexualidade no Brasil deixaram de lado as particularidades da maneira como se dão os relacionamentos afetivos entre sujeitos rurais quilombolas, talvez, em parte, por acreditarem que esses sujeitos copiavam os modelos de comportamentos produzidos nos grandes centros urbanos, sobretudo do centro-sul do País, ou talvez ainda por respeitarem outras agendas de pesquisa, geralmente respeitosas das demandas dos sujeitos 
de direitos que exigiam e exigem dos trabalhos acadêmicos o foco em outras questões (no caso dos quilombolas, por exemplo, nas questões relativas a território, meio ambiente, parentesco, cosmologia, dentre outros temas).

Nos trechos dos relatos acima apresentados de Pedro, Dênis, Bento e Alan, parece ficar claro, por um lado, que há alguma particularidade na maneira como os marcadores de corporalidade, ruralidade, racialidade, etnicidade, gênero e sexualidade percutem, se interceptam e se articulam nesses contextos de áreas rurais quilombolas, embora também fique claro, por outro lado, que os padrões heteronormativos são reproduzidos tal qual nos contextos urbanos (a partir de negociações peculiares): Pedro e Bento se afirmam, mais do que Dênis e Alan, como sujeitos quilombolas e rurais, lideranças locais; por serem marcados pela ruralidade, Pedro, Dênis e Bento, mais do que Alan, se afeminam de um certo jeito peculiar, como uma forma de se adequar ao jogo local que regula as relações de gênero e os relacionamentos afetivos e sexuais; Alan, por sua vez, não se afemina tanto, transgredindo as regras do jogo dos afetos, por isso deseja ir embora do quilombo e viver na cidade grande para deixar fluir seus desejos; Dênis e Alan sonham com um relacionamento estável e duradouro, uma "verdadeira" vida de casal, o que é impossível no contexto rural e quilombola onde vivem - um relacionamento estável e duradouro seria uma outra transgressão das regras do jogo dos afetos, uma infração da fluidez; todos os quatro conseguem manter relações sexuais dentro de suas comunidades, contanto que respeitem o equilíbrio sistêmico do fluxo de afetos e, sobretudo, que saibam gerenciar o dizível e o indizível, o visível e a visibilização e o permitido e o permissível, na medida da manutenção do equilíbrio; mas, Alan, mesmo mantendo relações dentro da sua comunidade, prefere homens de olhos claros, brancos, rompendo novamente com as regras do jogo, reproduzindo um certo tipo de fetichização do corpo negro ao se entregar aos homens "de fora" que visitam a comunidade durante as festividades locais. Essas são algumas particularidades situacionais dos contextos quilombolas em questão que tensionam, também situacionalmente, as experiências da diversidade sexual e de gênero.

Essas particularidades situacionais parecem apontar para o fato de que, mais do que duas realidades cristalizadas que se opõem, as realidades rurais quilombolas e as realidades urbanas dialogam e se fundem, funcionando como uma via de mão dupla: o mundo rural e quilombola não absorve passivamente o influxo do mundo urbano, mas negocia com este último de acordo com seus próprios interesses locais. Pedro, Dênis, Bento e Alan têm aparelhos de televisão em suas casas, acessam a rede internacional de computadores, fazem amizades nas redes sociais virtuais, são escolarizados (em maior ou menor grau), circulam entre comunidades, cidades e capitais, interagem com um grande número de pessoas... e selecionam o que lhes parece mais interessante, em cada um dos ambientes que frequentam, para compor suas formas 
particulares de pertencimento: eis a dinâmica cultural em ação. Comunidades rurais quilombolas não são entes fechados, mas fazem parte de um mundo global em transformação. Com Pedro, Dênis, Bento e Alan, aprendemos que ser quilombola é mais do que ser descendente de africanos escravizados trazidos à força para o trabalho braçal nas Américas. Ser quilombola é também um estar-no-mundo nos dias de hoje, produzindo diferenças e reconhecimento para viabilizar a igualdade e a paridade.

\section{AGRADECIMENTOS}

Agradecemos ao Conselho Nacional de Desenvolvimento Científico e Tecnológico (CNPq) pela bolsa de Produtividades em Pesquisa para o primeiro autor e pelas bolsas de Iniciação Científica para os dois outros autores. As bolsas viabilizaram a realização da pesquisa.

\section{NOTAS}

${ }^{1}$ Ver Acevedo Marín \& Castro (1998), Arruti (2006), Duprat (2007), Fiabani (2005), Gomes (1997), Leite (1999, 2000,2008), Martins (2006), Moura (1981), Oliveira (2016), O’Dwyer (2002), Reis \& Gomes (1996), Treccani (2006), dentre tantos outros - em comum, pode-se dizer que esses textos definem os quilombos rurais como compostos por uma "territorialidade específica", uma identidade de cunho étnico e um histórico de resistência à escravização.

${ }^{2}$ Encontramos, todavia, estudos sobre as particularidades das relações de gênero e sobre a interface entre gênero e etnicidade, como, por exemplo, no texto esclarecedor de O’Dwyer (2016).

${ }^{3}$ Foi negociado com os interlocutores que seriam usados nomes fictícios para designá-los e que os nomes de seus quilombos não seriam citados, já que o uso dos nomes reais poderia acarretar em formas de represália ou usos indevidos dos dados, não só por parte de outros moradores dos quilombos, mas sobretudo de grileiros e fazendeiros que vêm atuando principalmente no quilombo marajoara $\mathrm{e}$ também de moradores das cidades próximas frequentadas por esses jovens rapazes. As entrevistas com Pedro e Dênis foram realizadas por Fabiano Gontijo, Daniel Oliveira da Silva e Célia da Silva Costa em maio e outubro de 2012 (a Daniel e a Célia, nossos agradecimentos), ao passo que as entrevistas com Bento e Alan foram realizadas por Bruno Rodrigo Carvalho Domingues ao longo de 2016. As entrevistas foram realizadas e analisadas de acordo com as recomendações de Bertaux (2005), Feal (1990), Gonçalves et al. (2012) e Peneff (1990), levando-se em consideração a maneira como os interlocutores se constituem como sujeitos e dão sentido a suas vidas, através da discursividade elaborada no processo de entrevista (Foucault, 2007, foi de grande importância para se pensar a relevância dos discursos e sua transformação em discursividades). Igor Erick contribuiu nesse artigo com as análises e interpretações das entrevistas.

${ }^{4}$ Há um grande projeto de pesquisa e extensão cadastrado na Universidade Federal do Piauí, envolvendo pesquisadores brasileiros e estrangeiros, sendo desenvolvido em algumas comunidades quilombolas situadas na região norte do estado do Piauí. Em 2012, Fabiano Gontijo e dois estudantes da UFPI, foram convidados a visitar uma das comunidades. Durante a estadia, os pesquisadores conheceram e conversaram com Pedro. Numa segunda visita, ainda em 2012, os pesquisadores conheceram e conversaram com Dênis. Agradecemos a uma das coordenadoras do projeto, pelo 
convite e pela facilitação de acesso à comunidade (preferimos não nomeá-la aqui para evitar toda e qualquer possibilidade de identificação da comunidade em questão). Agradecemos ainda às lideranças da comunidade, que autorizaram o acesso à comunidade, mostrando-se muito interessadas pela temática da pesquisa. Enfim, agradecemos a Pedro, Dênis e a Antônio por terem conversado com os pesquisadores. Apresentaremos a maneira como Fabiano e os dois estudantes chegaram até Pedro, Dênis e Antônio para a realização das conversas e entrevistas e as principais informações coletadas pelos pesquisadores, deixando de lado, momentaneamente, os outros dois autores desse artigo, Bruno e Igor.

5 As aspas serão usadas, a partir daqui, sempre que se tratarem de trechos das falas dos interlocutores.

${ }^{6}$ As informações sobre a história da comunidade foram obtidas através de um site de divulgação da própria comunidade (não podemos divulgar o endereço do site aqui, pois isso permitiria a identificação da comunidade) e as informações sobre a certificação, do site da Fundação Palmares: http://www.palmares.gov.br/wp-content/ uploads/2016/06/COMUNIDADES-CERTIFICADAS.pdf

${ }^{7}$ Respectivamente, Attalea speciosa, Mauritia flexuosa e Copernicia prunifera.

${ }^{8}$ Programas dos Governos Federal e Estadual, através da Caixa Econômica Federal, ajudaram a substituir as antigas casas de taipa ou pau-a-pique por casas de alvenaria, mais resistentes. No entanto, a população continua construindo cômodos de taipa agregados às casas principais, já que as casas de taipa se adequam melhor a algumas necessidades habitacionais locais.

${ }^{9}$ As informações estruturais sobre a comunidade foram fornecidas por Daniel
Oliveira da Silva e encontram-se nos relatórios produzidos a partir das duas visitas à comunidade.

${ }^{10}$ Embora Bento seja um conhecido dos três autores desse artigo, a entrevista foi concedida a Bruno Rodrigo Carvalho Domingues durante sua estadia no quilombo para a realização de uma outra pesquisa. Sendo assim, apresentaremos a maneira como Bruno chegou até Bento e ate Alan para a realização da entrevista e as principais informações coletadas, deixando de lado, por enquanto, os outros dois autores do artigo.

${ }^{11}$ Trata-se de um projeto de pesquisa sobre "ecologia de saberes" (Santos, 2007) sob a coordenação de um antropólogo da Universidade Federal do Pará (preferimos não nomeá-lo aqui para evitar toda e qualquer possibilidade de identificação da comunidade em questão). Bruno é orientando de Iniciação Científica desse Professor A ele, nosso agradecimento pela disponibilidade em colaborar com nossa pesquisa.

${ }^{12}$ Em Santarém, no interior do Pará, em pesquisa que está sendo realizada por $\mathrm{Fa}$ biano Gontijo e Igor Erick, percebe-se uma dinâmica de uso dos espaços semelhante à relatada por Bento, mas muito diferente daquela apresentada nos estudos sobre sociabilidades homossexuais nos contextos dos grandes centros urbanos do eixo centro-sul do Brasil (Gontijo \& Erick 2017, no prelo). Semelhanças são encontradas também com as pesquisas de Ferreira (2006) ou Nascimento (2012).

${ }^{13}$ Noção apresentada, dentre outros, por Perlongher (1987) no contexto urbano. Usando Levine, o autor define os guetos enquanto culturais e residenciais. Propõe que se pense o gueto enquanto um espaço socialmente determinado, ou construído, utilizados por pessoas homossexuais para finalidades diversas, distante dos olhos e do preconceito social, sem que seja neces- 
sário contabilizar uma grande quantidade de indivíduos. Não podemos, portanto, auferir o mesmo sentido de Perlongher, pois estamos trabalhando em um contexto quilombola, onde os espaços de sociabilidade são radicalmente distintos dos espaços de sociabilidade urbanos.

${ }^{14}$ Bactris maraja (marajá) é uma palmeira frequente nas margens de lagos e igarapés amazônicos, cujos frutos comestíveis são consumidos por homens e animais.

${ }^{15}$ Euterpe oleracea Mart.

${ }^{16}$ Fora da capital paraense, é comum associar "andar" com "relacionar-se"; portanto, quando o interlocutor diz "anda com mulher", diz que "se relaciona com mulher".

${ }^{17}$ É importante diferenciar o "andar" de "ficar" no discurso de Alan, pois durante a entrevista, ficou nítido que "andar" é contínuo, é relacionar-se de forma duradoura, ao passo que "ficar" é esporádico e ocasional.

${ }^{18}$ Termo do bajubá que, segundo nosso interlocutor, significa "gay que só anda com macho feio, que não se veste bem, que só vive relaxado". Bajubá, por sua vez, é o "Nome que os homossexuais dão às gírias por eles utilizadas, incluindo nelas não somente as palavras, mas todo um jogo corporal que permite o entendimento mais apurado dos termos do bajubá." (Silva Filho \& Palheta 2008).

19 “' que é o moreno?” Perguntou Bruno a Alan. E ele respondeu: "Moreno é alguém mais escuro que eu, tu, por exemplo, é moreno".

\section{REFERÊNCIAS}

Acevedo Marín, R. E. \& E. R. Castro (orgs.). 1998. Negros do Trombetas: guardiōes de matas e rios. Belém: EdUFPA/NAEA.

Acevedo Marín, R.E., Teles, E. , Cardoso,
M.S.C. \& D. B. Santos (orgs.). 2015. Povos Tradicionais no Arquipélago do Marajó e Politicas de Ordenamento Territorial e Ambiental. Rio de Janeiro: CASA 8.

Arruti, J. M. 2006. Mocambo: antropologia e história de formação do processo quilombola. Bauru: EDUSC.

Bertaux, D. 2005. Le Récit de Vie. Paris: Armand Collin.

Bozon, M. e M. L. Heilborn. 2001. As carícias e as palavras: iniciação sexual no Rio de Janeiro e em Paris. Novos Estudos CEBRAP n. 59: 111-135.

Brasil. 2003. Decreto $n^{\circ} 4.887$, de 20 de novembro de 2003. Disponível em: http://www.planalto.gov.br/ccivil_03/decreto/2003/d4887.htm

Butler, J. 2000. Corpos que Pesam: sobre os limites discursivos do "sexo". In: Louro, G. L. (org.). O corpo educado. Pedagogias da sexualidade. Belo Horizonte: Autêntica, pp. 151-168.

2003. Problemas de Gênero: feminismo e subversão da identidade. Rio de Janeiro: Civilização Brasileira.

DaMatta, R. 1987. Digressão: A fábula das três raças, ou o problema do racismo à brasileira, in Relativizando: uma introdução à antropologia social. Rio de Janeiro: Rocco.

Duprat, D. (org.) 2007. Pareceres Jurídicos: direitos dos povos e comunidades tradicionais. Manaus: EdUEA.

Feal, R. 1990. Spanish American Ethnobiography and the Slave Narrative Tradition: "Biografía de un Cimarrón” y "Me Llamo Rigoberta Menchú". Modern Language Studies $\mathrm{v}$. 20, n. 1: 100-111.

Fernandes, E. R. 2015. Descolonizando Sexualidades: enquadramentos coloniais e homossexualidade indígena no Brasil e nos Estados Unidos. Tese de Doutorado, Programa de Pós-Graduação em Estudos Comparados so- 
bre as Américas, Universidade de Brasília. Ferreira, P. R. 2006. Os Afectos Mal-Ditos: o indizivivel das sociedades camponesas. Dissertação de Mestrado, Programa de Pós-Graduação em Antropologia Social, Universidade de Brasília.

Fiabani, A. 2005. Mato, palhoça e pilão: o quilombo, da escravidão às comunidades remanescentes (1532-2004). São Paulo: Expressão Popular.

Foucault, M. 2001. Microfísica do poder. Rio de Janeiro, Graal. 2007. A Ordem do Discurso. São Paulo: Loyola. 2015. História da Sexualidade. 1: A Vontade de Saber. Rio de Janeiro: Paz \& Terra.

Fry, P. 1982. Da hierarquia à igualdade: a construção histórica da sexualidade no Brasil, in Para inglês ver: identidades e política na cultura brasileira. Rio de Janeiro: Zahar, pp. 87-115.

Giraldo, F. U., Arias, W. B. \& J. I. Reyes. 2007. Tensiones en La Construcción de identidades de Hombres Negros Homosexuales en Cali. Manuscrito.

Gomes, F. A. 1997. A Hidra e os Pântanos: quilombos no Brasil (sécs. XVII-XIX). Tese de Doutorado. Programa de Pós-Graduação em História, Universidade de Campinas.

Gonçalves, M. A. et al. (org.). 2012. Etnobiografia - subjetivação e etnografia. Rio de Janeiro: 7 Letras.

Gontijo, F. 2015. Sexualidade e Ruralidade no Brasil: o que os estudos rurais e os estudos de gênero e sexualidade (não) dizem sobre essa relação? Vivência n. 45: 145-158.

Gontijo, F. \& I. Erick. 2015. Diversidade Sexual e de Gênero, Ruralidade, Interioridade e Etnicidade no Brasil: Ausências, Silenciamentos e... Exortações. ACENO v. 2, n. 4: 24-40.
2017. Sexualidades

em Sociabilidades em Santarém: outras histórias, outras dinâmicas. No prelo.

Gonzalez, L. 1984. Racismo e Sexismo na Sociedade Brasileira. Revista Ciências Sociais Hoje, Anpocs, 223-244.

Guimarães, A. S. A. 2004. Preconceito de Cor e Racismo no Brasil. Revista de Antropologia v. 47, n. 1: 9-43.

Junqueira, R. D. 2012. Homofobia: limites e possibilidades de um conceito em meio a disputas. Bagoas n 1, v. : 1-22.

Kilomba, G. [2010] 2016. “The Mask”, in Plantation Memories: Episodes of Everyday Racism. Münster: Unrast Verlag.

Leite, I. B. 1999. Quilombos e quilombolas: cidadania ou folclorização? Horizontes Antropológicos, Porto Alegre n. 10: 123-149. 2000. Os quilombos no Brasil: questões conceituais e normativas. Etnográfica v. IV, n. 2: pp. 333-354.

2008. O Projeto Político Quilombola: desafios, conquistas e impasses atuais. Revista Estudos Feministas v. 16, n. 3: 965-977.

Marques, C. E. \& L. Gomes. 2013. A Constituição de 1988 e a Ressignificação dos Quilombos Contemporâneos: limites e potencialidades. Revista Brasileira de Ciências Sociais v. 28, n. 81: 137-255.

Martins, C. F. 2006. As Fronteiras da Liberdade: o campo negro como entre-lugar da identidade quilombola. Dissertação de Mestrado, Programa de Pós-Graduação em Estudos Comparados sobre as Américas, Universidade de Brasília.

Miskolci, R. 2008. O Corte da Sexualidade: A emergência do dispositivo de sexualidade no Brasil. Anais da $26^{a} \mathrm{RBA}$.

2009. A Teoria Queer e a Sociologia: o desafio de uma analítica da normalização. Sociologias v. 11, n. 21: 150-182. 
2012. O Desejo da Nação: masculinidade e branquitude no Brasil de fins do XIX. São Paulo: Annablume Editora/ FAPESP.

Moura, C. 1981. Quilombos e a Rebelião Negra. São Paulo: Brasiliense.

Moutinho, L. 2004a. Discursos Normativos e Desejos Eróticos: a arena das paixões e dos conflitos entre brancos e negros. $S_{e-}$ xualidade, Gênero e Sociedade 20: 1-7.

2004b. Raz̃ão, "Cor" e Dese-

jo: uma análise comparativa sobre relacionamentos afetivo-sexuais "inter-raciais" no Brasil e na Africa do Sul. São Paulo: EdUNESP.

Munanga, K. 2007. Considerações sobre as Políticas de Ação Afirmativa no Ensino Superior, in Pacheco, J. Q e M. N. Silva (orgs.). O negro na universidade: o direito a inclusão. Brasília, DF : Fundação Cultural Palmares.

McCallum, C. 2013. Nota sobre as Categorias "Gênero" e "Sexualidade" e os Povos Indígenas. Cadernos Pagu 41: 53-61.

Nascimento, S. 2012. Homem com Homem, Mulher com Mulher: paródias sertanejas no interior de Goiás. Cadernos Pagu 39: 367-402.

Nogueira, O. 2007. Preconceito Racial de Marca e Preconceito Racial de Origem. Tempo Social v. 19, n. 1: 287-308.

Oliveira, O. M. (org.). 2016. Direitos Quilombolas \& Dever de Estado em 25 Anos da Constituição Federal de 1988. Rio de Janeiro: ABA.

O’Dwyer, E. C. 2016. Uma Nova Forma de Fazer História: os direitos às terras de quilombo diante do projeto modernizador de construção da Nação, in Oliveira, O. M. (org.). Direitos Quilombolas \& Dever de Estado em 25 Anos da Constituição Federal de 1988. Rio de Janeiro: ABA, pp. 257-273.

O'Dwyer, E. C. (org.). Quilombos: identidade étnica e territorialidade. Rio de Janeiro: Edito- ra FGV/ABA, 2002.

Parker, R. 1991. Corpos, pazeres e paixões: cultura sexual no Brasil contemporâneo. São Paulo: Best Seller.

Peneff, J. 1990. La Métode Biographique. Paris: Armand Collin.

Perlongher, N. 1987. O Negócio do Michê: prostituição viril em São Paulo. São Paulo: Brasiliense.

Reis, J. J. \& F. S. Gomes. (orgs.). 1996. Liberdade por um Fio: história dos quilombos no Brasil. São Paulo: Companhia das Letras.

Rich, A. 1983. Compulsory Heterosexuality and Lesbian Experience, in Snitow, A.; Stansel, C. e S. Thompson (Orgs.). Powers of Desire - The Politics of Sexuality. Nova York: Monthly Review Press, pp. 177-215.

Santos. B. S. 2007. Para além do pensamento abissal: das linhas globais a uma ecologia de saberes. Novos Estudos CEBRAP 79: 71-94.

Sedgwick, E. K. 2007. A Epistemologia do Armário. Cadernos Pagu 28: 19-54.

Silva Filho. M. R. 2013. "Só foi inesquecível porque foi a primeira vez, né?!”: Práticas, dizeres e imaginários sobre iniciação sexual e marcadores sociais da diferença entre jovens homens da periferia de Belém-Pará, in Conrado. M. (org.). Juventudes em trânsito: Iniciação sexual em debate. Editora Paka-Tatu: Belém.

Silva Filho, M. R. \& S. P. Palheta. 2008. Ser ou Não Ser? Os gays em questão: uma leitura antropológica das gírias utilizadas pelos homossexuais de Belém-PA. Anais da $26^{a} \mathrm{RB} A$.

Treccani, G. D. 2006. Terras de Quilombo: caminhos e entraves do processo de titulação. Belém: Programa Raízes.

Recebido entre 24 a 27/02/17

Aprovado em 21/03/17 